\title{
Hamulec klockowy i niektóre aspekty cieplnych uszkodzeń kól
}

\begin{abstract}
W najbliższej przyszłości hamulce tarczowe i klockowe będq nadal podstawowa forma układów hamulcowych sterowanych pneumatycznie w pojazdach szynowych. Hamulce tarczowe pozostana przede wszystkim hamulcami realizujacymi duże moce hamowania. W zastosowaniach $w$ wagonach towarowych jak również $w$ pojazdach o prędkościach maksymalnych do $120 \mathrm{~km} / \mathrm{h}$ i na większe prędkości $w$ ściśle określonych warunkach brzegowych, hamulec klockowy jest nadal interesujacy ze względu na niskie koszty produkcji i niskie koszty eksploatacji. $W$ artykule przedstawiono czynniki majqce wplyw na zakres stosowalności hamulca klockowego $i$ warunki brzegowe jego stosowania, szczególnie $w$ aspekcie różnych rodzajów materiatów wstawek hamulca klockowego (żeliwnych i kompozytowych), oraz uszkodzeń cieplnych kót.
\end{abstract}

\section{Wstęp}

Aktualnie nie można zrezygnować $\mathrm{z}$ hamulców pneumatycznych w pojazdach trakcyjnych komunikacji regionalnej i dalekobieżnej a przede wszystkim $\mathrm{w}$ pociagach ciągnionych przez lokomotywy. Przy tym sprężone powietrze, jako medium, jest konieczne nie tylko do wytworzenia siły hamowania, ale również jest używane w klasycznym wykonaniu hamulca pneumatycznego jako czynnik sterowania hamulcami $\mathrm{w}$ całym pociągu. Szczególnie w długich pociaggach $\mathrm{z}$ powodu skończonych prędkości rozchodzenia się fali hamowania w przewodzie głównym, powstają problemy wynikające $\mathrm{z}$ coraz późniejszego wejścia do pracy hamulców wzdłuż pociągu, co prowadzi do wydłużenia drogi hamowania a dla małych prędkości pociagu do pojawienia się znacznych sił wzdłużnych, które powodować mogą niejednokrotnie wykolejenia. Zmniejszenie tych wad realizowane jest od dawna przez zastosowanie $\mathrm{w}$ hamulcach UIC nastawienia „pospieszny”, „osobowy” czy „towarowy” (w zależności od potrzeb eksploatacyjnych), albo przez zastosowanie hamulców sterowanych elektrycznie (hamulce EP w zespołach trakcyjnych i pociagach na duże prędkości). Dodatkowo współczesne pojazdy trakcyjne są dzisiaj wyposażane $\mathrm{w}$ hamulec elektrodynamiczny (ED), aby:

- uzyskana energia elektryczna podczas hamowania (z energii kinetycznej) mogła być wykorzystana do napędu innych pojazdów lub ich napędów pomocniczych

- ograniczyć stosowanie hamulców ciernych sterowanych pneumatycznie tak, by zmniejszyć zużycie par ciernych (wstawek hamulca klockowego, powierzchni tocznej kół, okładzin ciernych i tarcz hamulcowych) poprzez zmniejszenie do minimum energii rozpraszanej przez te układy.

Dzięki temu zwiększa się wielokrotnie żywotność par ciernych, a co za tym idzie zmniejsza się bardzo istotnie koszty eksploatacji.
Mimo stosowania hamulców elektropneumatycznych i elektrodynamicznych, $\mathrm{z}$ hamulca pneumatycznego nadal nie można zrezygnować ze względów bezpieczeństwa. Nie tylko dlatego, że awaria tych hamulców nie jest wykluczona, ale również dlatego, że względnie proste jest wykazanie właściwego bezpieczeństwa pojazdu $\mathrm{z}$ hamulcem ciernym $\mathrm{w}$ ramach wymaganych dzisiaj warunków dopuszczenia pojazdów do ruchu.

Hamulec cierny sterowany pneumatycznie służy, jako nieodzowny hamulec zapewniający bezpieczeństwo pociagu $\mathrm{w}$ hamowaniach służbowych, nagłych, uruchamianych w nagłych przypadkach przez pasażerów i wymuszonych innymi układami (SHP, czuwak czy radiostop), jak również jako hamulec postojowy. Dodatkowo stosowany jest we wszystkich liniowych lub manewrowych lokomotywach jako dobrze stopniujący się hamulec dodatkowy.

Klasyczna formą hamulca sterowanego pneumatycznie jest hamulec klockowy, który na początku był stosowany $\mathrm{w}$ postaci impregnowanych klocków drewnianych, który jednak bardzo wcześnie z powodu niewystarczającej odporności na temperaturę i niskie współ1)czynniki tarcia na „mokro” został zastapiony klockami żeliwnymi. W trakcie wielu dziesiątków lat eksploatacji zwiększano odporność tych klocków (wstawek) na zużycie poprzez podniesienie zawartości fosforu. Dalsze poszukiwania wstawek o małym zużyciu (wyższej żywotności eksploatacyjnej) i o bardziej stałym przebiegu współczynnika tarcia w funkcji prędkości, stały się przed 25 laty powodem rozwoju w Europie wielu rodzajów klocków z tworzyw kompozytowych (o różnych parametrach użytkowych). Znalazły one szerokie zastosowanie $\mathrm{w}$ pojazdach szynowych, jakkolwiek budzily na początku wiele wattpliwości i zastrzeżeń, które wynikały przede wszystkim z konieczności wdrożenia nieco innej techniki prowa- 
dzenia pociagów. Wstawki $\mathrm{z}$ tworzyw kompozytowych są powszechnie stosowane od wielu lat w pojazdach trakcyjnych i wagonach osobowych (lokomotywy manewrowe, zespoły trakcyjne strego typu np. S-Bahn w DB, wagony osobowe Federacji Rosyjskiej), a ostatnio wdrażane są $\mathrm{w}$ wagonach towarowych w całej Europie. Pociagi z tymi wstawkami eksploatowane są w każdych warunkach klimatycznych, a wieloletnie doświadczenia kolei europejskich $\mathrm{w}$ ich stosowaniu stały się podstawą do opracowania przez podkomisję hamulcową UIC (5T „Hamulce”) obowiązujących wytycznych ich bezpiecznego eksploatowania [1]. Głównym powodem wdrażania do wagonów towarowych wstawek z tworzyw kompozytowych jest konieczność zredukowania hałasu pojazdów szynowych (pociągów), zwłaszcza podczas jazdy i hamowania. Rozwiązanie to znalazło duże zainteresowanie jako rozwiązanie alternatywne w stosunku do hamulca tarczowego, gdyż oba rozwiązania w równym stopniu skutecznie eliminuja hałas toczenia i hamowania pojazdu, przy czym hamulec klockowy jest bardziej interesujący ze względu na bardzo niskie koszty produkcji i niskie koszty eksploatacji. Mimo to hamulec tarczowy jest dzisiaj dominującą formą budowy hamulca w wagonach osobowych i pojazdach trakcyjnych wszędzie tam, gdzie wymagane są duże moce hamowania, które występują $\mathrm{w}$ taborze dalekobieżnym, poruszającym się z coraz większymi prędkościami (200 km/h i więcej).

\section{Obciążenia cieplne i mechaniczne hamowanego \\ koła}

Procesem hamowania pojazdu jest zamiana jego energii kinetycznej $\mathrm{w}$ inne postacie energii $\mathrm{w}$ celu zmniejszenia jego prędkości lub zatrzymania. Energia kinetyczna pojazdu zamieniana jest $\mathrm{w}$ układach ciernych hamulca na następujące postacie energii:

- ciepło

- odkształcenia sprężyste i plastyczne

- drgania

- nośność hydrodynamiczną

- przenikanie i pochłanianie molekuł par ciernych

- topnienie,

- rekrystalizację

- rozpad i powstawanie związków chemicznych zarówno na powierzchni tarcia jak i w głębi materiałów itp.

Im większy jest udział energii cieplnej w stosunku do innych rodzajów energii, tym materiał cierny jest bardziej odporny na zużycie. Zdecydowana większość energii pojazdu $\mathrm{w}$ procesie hamowania jest zamieniana na energię cieplną. Energia ta rozpraszana jest w skończonym czasie (hamowania), prowadząc do powstania dużych mocy hamowania realizowanych przez parą cierną. Na rys.1 pokazano przykładowe przebiegi chwilowych mocy hamowania dla różnych pojazdów szynowych podczas hamowania nagłego (do zatrzymania) realizowane przez jedno koło lub tarczę.

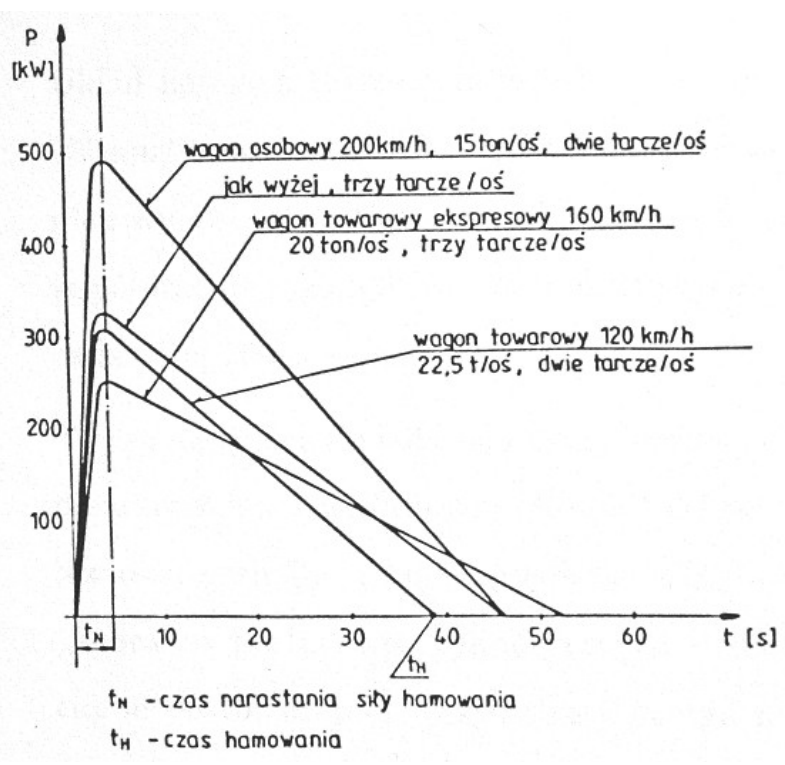

Rys.1 Przebieg chwilowych mocy hamowania przypadających na jedną tarczę lub koło w funkcji czasu podczas hamowania nagłego różnych pojazdów szynowych.

Powstały w tym procesie strumień cieplny (będący mocą hamowania) dzieli się na dwa główne strumienie: wpływający do koła i do wstawki (lub tarczy i okładziny).

Współczynnik rozdziału strumienia cieplnego dla koła hamowanego wstawką hamulca klockowego wynosi [2]:

$$
\alpha_{k}=\frac{1}{1+\frac{A_{k l o c k a}}{A_{k}} \sqrt{\frac{\lambda_{k l} \cdot \gamma_{k l} \cdot c_{k l}}{\lambda_{k} \cdot \gamma_{k} \cdot c_{k}}}}
$$

gdzie: $A_{\text {klocka }}$ - powierzchnia tarcia klocka (wstawki),

$\mathrm{A}_{\mathrm{k}}$ - powierzchnia współpracy koła $\mathrm{z}$ klockiem,

$\lambda, \gamma, \mathrm{c}$ - przewodność cieplna, masa właściwa i ciepło właściwe odpowiednio materiału klocka i koła.

Dla parametrów geometrycznych i cieplnych hamulca klockowego żeliwnego pojazdów szynowych współczynnik $\alpha_{k}$ wynosi około 0,7 ; to znaczy, że około $70 \%$ energii cieplnej wpływa do koła (a około $30 \%$ do wstawki). Dla hamulca klockowego kompozytowego, przede wszystkim ze względu na mniejszy współczynnik przewodności $\lambda_{\mathrm{kl}}$ wstawki, współczynnik $\alpha_{\mathrm{k}}$ wynosi około 0,8 . Mimo korzystniejszego współczynnika rozdziału strumienia cieplnego dla wstawek żeliwnych, wstawki kompozytowe lepiej współpracując (większą powierzchnią rzeczywistą kontaktu) z powierzchnią koła nie prowadzą do istotnie większych temperatur miejscowych koła, gdyż bardziej równomiernie wprowadzają ciepło do koła.

Wstawka z żeliwa nagrzewając się w niewielkiej warstwie podczas pierwszych kilkunastu sekund hamowania doznaje odkształcenia na skutek pojawiającego się gradientu temperatury, który powoduje 
wewnętrzne naprężenia termiczne. Odkształcenie to powoduje bardzo istotne zmniejszenie powierzchni kontaktu rzeczywistego wstawki z kołem. W kole natomiast powstający gradient temperatury po promieniu koła prowadzi do wytworzenia się naprężeń termicznych ściskających. Maksymalne naprężenia pojawiające się na powierzchni tocznej koła na skutek nagrzewania dla bardzo dużych prędkości i dużych opóźnień pojazdu mogą osiągnąć nawet ponad 400 $\mathrm{N} / \mathrm{mm}^{2}$ [4].

$\mathrm{Na}$ rys.2 pokazano fotografię powierzchni tarcia wstawki po hamowaniach nagłych, na którym widać wyraźne zmniejszenie się rzeczywistej powierzchni kontaktu.

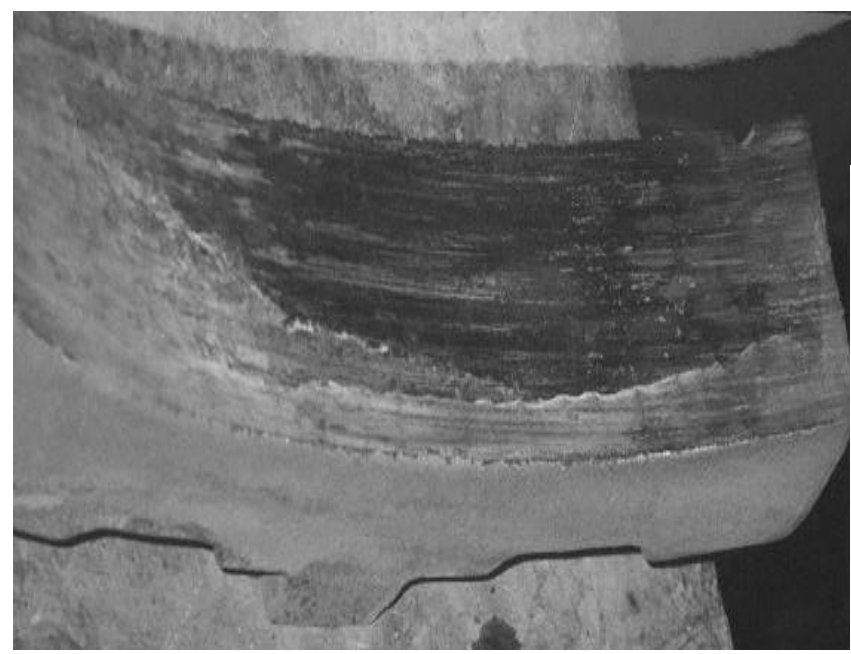

Rys.2 Powierzchnia wstawki żeliwnej po próbach hamowania nagłego

Odkształcenie wstawki prowadzi do zwiększenia jednostkowego strumienia cieplnego $\left(\mathrm{kW} / \mathrm{cm}^{2}\right)$ wpływającego zarówno do wstawki jak i do koła. Prowadzi to do powstania miejscowych wysokich temperatur na powierzchni tocznej kół, co $\mathrm{W}$ powiązaniu $\mathrm{z}$ dużą twardością żeliwa prowadzi do pojawienia się zjawiska niestabilności termosprężystej zogniskowanej (tzw. miejscowych przegrzań - hot spot). W takiej sytuacji miejscowe temperatury na powierzchniach ciernych wstawki i koła mogą przekraczać $1000^{\circ} \mathrm{C}$. Tak wysokie temperatury wywołują intensywne iskrzenie a niekiedy nawet zapłon produków zużycia, co powodować może pożary terenów przytorowych. Zjawisko takie pokazano na fotografii na rys 3 .

Wstawki kompozytowe nie odkształcają się tak jak wstawki żeliwne, a przy właściwie dobranej twardości do wymaganego zakresu zastosowania nie wywołuja zjawiska niestabilności termosprężystej zogniskowanej koła, dzięki czemu temperatury miejscowe i ich gradienty $\mathrm{w}$ kole są wielokrotnie niższe podczas hamowania i nie stwarzają zagrożenia pożarowego.

Przykładową zależność granicznej twardości okładziny kompozytowej w funkcji prędkości pojazdu nie powodującej niestabilności termosprężystej zogniskowanej pokazano na rys.4 [3].

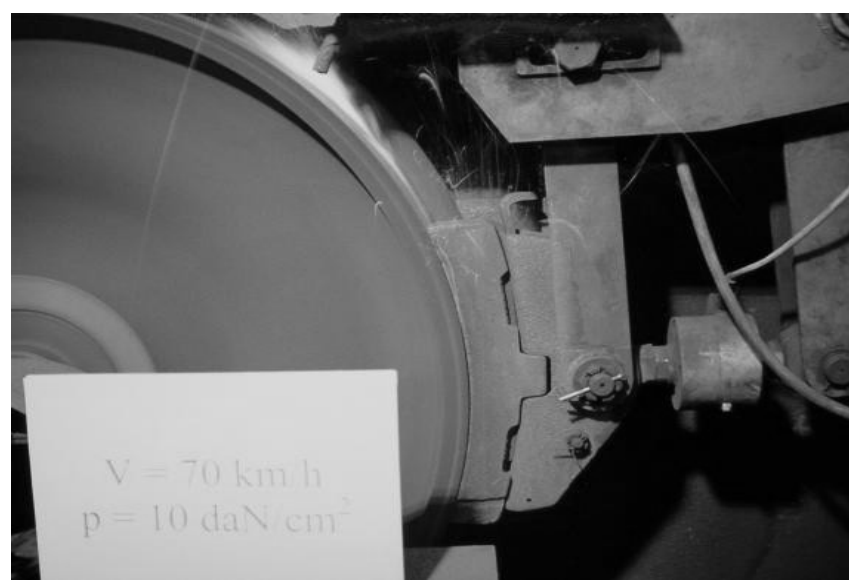

Rys.3 Zapłon produktów zużycia na skutek niestabilności termosprężystej zogniskowanej wstawki żeliwnej podczas hamowania nagłego (prędkość początku hamowania 70 $\mathrm{km} / \mathrm{h}$, nacisk jednostkowy $10 \mathrm{daN} / \mathrm{cm}^{2}$, masa $12 \mathrm{t} /$ koło)

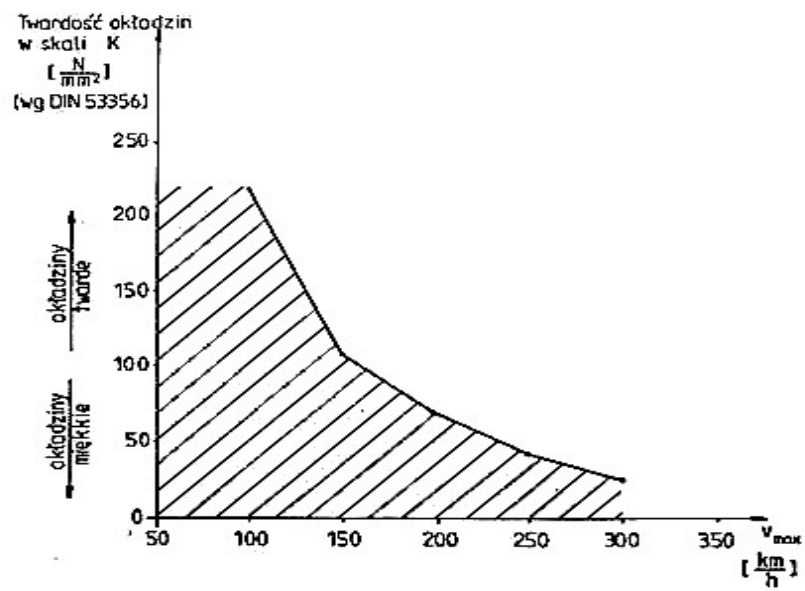

Rys.4 Graniczna twardość organicznych okładzin kolejowych w funkcji prędkości pojazdu nie powodująca niestabilności termosprężystej zogniskowanej tarcz hamulcowych

Wstawki kompozytowe nie prowadzące do niestabilności termosprężystej zogniskowanej koła wywołuja niższe miejscowe temperatury $\mathrm{w}$ kole $\mathrm{i}$ tym samym niższe naprężenia cieplne.

Podczas toczenia się kół po szynie w miejscu styku koła i szyny pojawiają się naprężenia zwane naprężeniami kontaktowymi. Naprężenia te, występujące na niewielkim obszarze koła, również są ściskające (tak jak naprężenia termiczne) i osiagają znaczne wartości. $\mathrm{Na}$ skutek toczenia się kół po szynie wartość tych naprężeń zależy od prędkości, nacisku koła na szynę i od średnicy koła. Przekraczają one granicę plastyczności materiału koła na głębokości kilku milimetrów. Naprężenia zredukowane $\sigma_{\varphi} \mathrm{W}$ tym obszarze są proporcjonalne do $\sqrt{\varphi \frac{Q}{D}}$, gdzie: $\varphi$ jest współczynnikiem zależnym przede wszystkim od prędkości jazdy, Q - obciążeniem koła, a D - średnicą koła. Naprężenia te osiągają wartość około $350 \mathrm{~N} / \mathrm{mm}^{2}$ [4]. Dodatkowo koła obciążone są stycznymi siłami od poślizgów wzdłużnych, poprzecznych i krętych. 


\section{Graniczna obciążalność koła hamowanego ha- mulcem klockowym i najczęściej spotykane uszkodzenia powierzchni tocznej kół}

Obciążenia cieplne i mechaniczne materiału koła wyznaczają granicę stosowalności hamulca klockowego pokazaną na rys.5 [4].

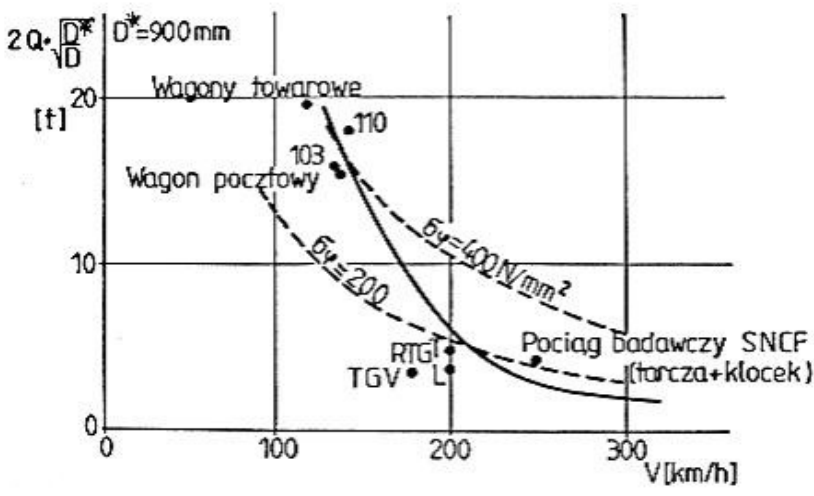

Rys.5 Graniczne obciążenia pary ciernej koło - klocek żeliwny pojazdów szynowych [3]

Superpozycja wyżej opisanych obciążeń prowadzi bowiem do przekroczenia granicy plastyczności na powierzchni tocznej oraz kilka milimetrów pod powierzchnią toczną koła. Przekroczenia te powoduja (już po kilkudziesięciu intensywnych hamowaniach) pojawienie się siatki termicznych pęknięć pokazanej na rys.6, a po dalszej eksploatacji wykruszanie się materiału obręczy kół z powierzchni tocznej tzw. pitting kól, pokazany na rys.7.

Zjawiska te pojawiają się zarówno we współpracy ze wstawkami żeliwnymi jak i ze wstawkami kompozytowymi. W przypadku wstawek żeliwnych obserwacja początkowych pęknięć termicznych jest utrudniona ze względu na zacieranie ich przez klocek (rowkowanie koła i permanentne tworzenie się połączeń adhezyjnych żeliwnych produktów zużycia $\mathrm{z}$ materiałem koła), ale drugi etap uszkodzeń tzw. pitting kół jest zjawiskiem powszechnie wystepującym w lokomotywach i wagonach intensywnie eksploatowanych $\mathrm{z}$ większymi prędkościami.

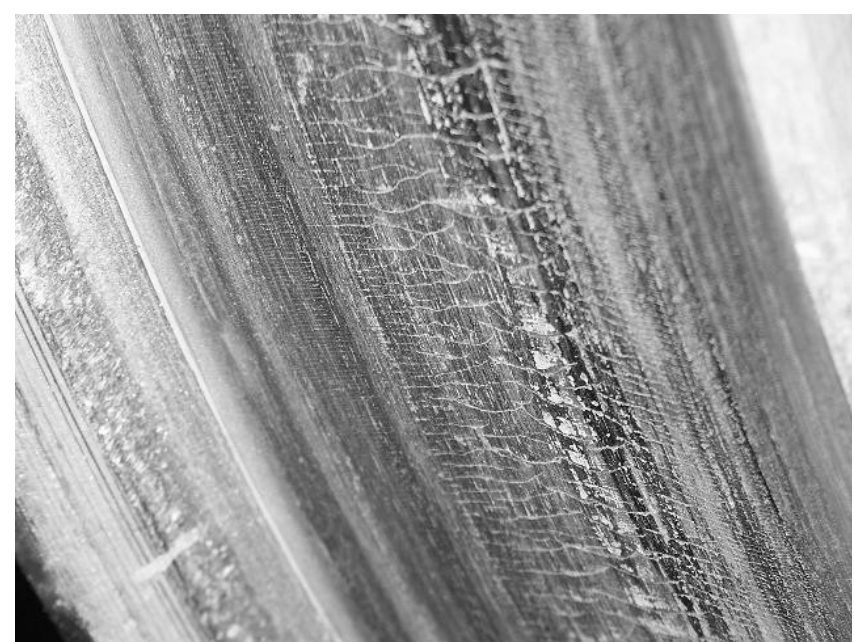

Rys.6 Siatka pęknięć termicznych na powierzchni koła

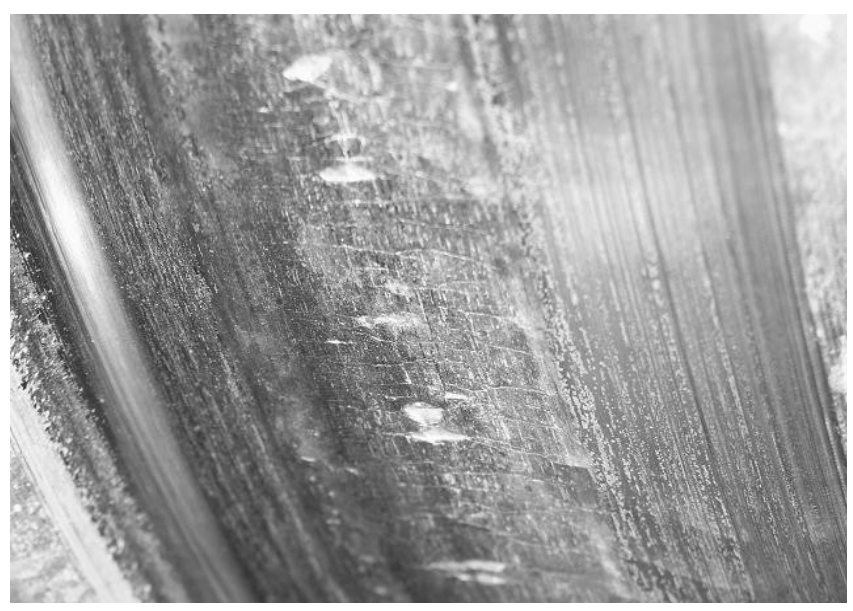

Rys.7 Wykruszenia materiału z powierzchni tocznej koła tzw. pitting

Wprowadzanie ciepła przez wstawkę podczas hamowania nie jest jedynym źródłem wprowadzania obciążeń cieplnych kół. Dużo bardziej groźne okazują się poślizgi kół po szynie [4] w trakcie zarówno rozruchu jak i hamowania. Na rys.8 pokazano przegrzanie miejscowe wywołane poślizgiem; granatowa obwódka niewielkiego płaskiego miejsca (na zdjęciu czarno białym widoczna jako ciemna obwódka w obszarze płaskiego miejsca) wskazuje na przekroczenie temperatury około $450^{\circ} \mathrm{C}$.

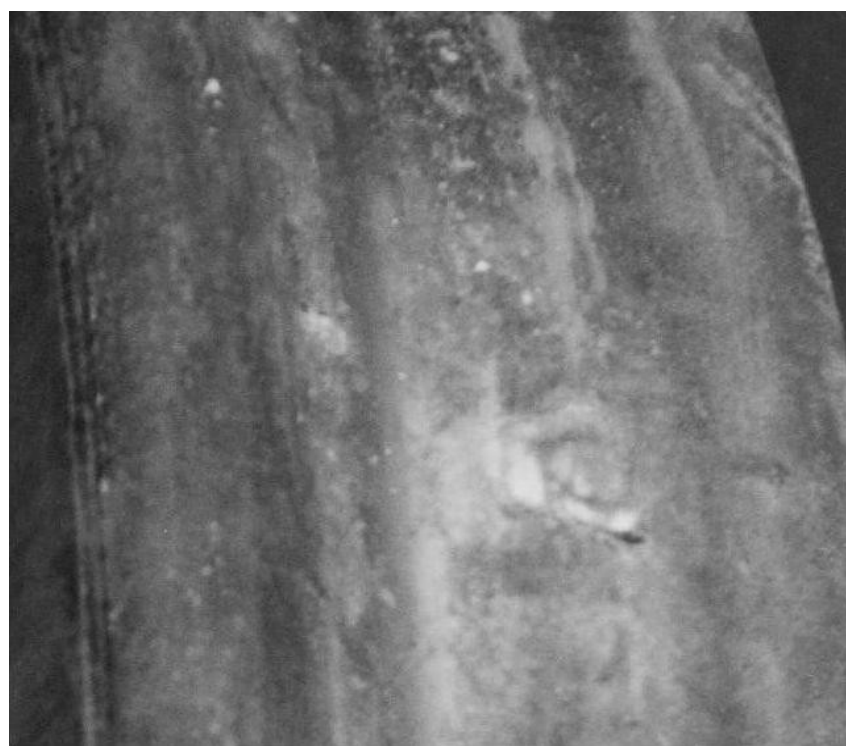

Rys.8 Podgrzanie miejscowe na powierzchni tocznej koła w wyniku poślizgu

Uszkodzenia $\mathrm{w}$ postaci wykruszeń materiału $\mathrm{z}$ powierzchni tocznej koła (tzw. Pitting koła) na skutek takiego obciążenia mogą się pojawić już po paru miesiącach niewłaściwej eksploatacji (np. po intensywnych rozruchach i hamowaniach w warunkach pogorszonej sezonowo przyczepności kół) bez stwierdzenia wyraźnych płaskich miejsc na kołach. Uszkodzenia takie obserwuje się często na lokomotywach, napędnych kołach zespołów trakcyjnych, ale również na wagonach osobowych wyposażonych $\mathrm{w}$ hamulec tarczowy! 
W celu ograniczenia takich uszkodzeń kół, w pojazdach hamowanych klockami i intensywnie eksploatowanych, montuje się nowoczesne układy przeciwpoślizgowe zarówno przy rozruchu jak i podczas hamowania, zmienia się materiał kół na bardziej odporny na pękania kruche i o większej wytrzymałości, rejestruje się każde bardzo intensywne hamowanie po którym wykonuje się płytkie przetoczenie [5]. Dzięki takim działaniom niektórym zarządom kolejowym udało się istotnie wydłużyć przebiegi lokomotyw hamowanych hamulcem klockowym. Przykład lokomotywy elektrycznej S 252 hiszpańskich kolei RENFE pokazuje, że przy pomocy takich eksploatacyjnych działań prewencyjnych z zakresu eksploatacji i technicznych warunków utrzymania taboru, żywotność kół może przekroczyć milion kilometrów przebiegu lokomotywy [6].

Mimo to, opisane wyżej uszkodzenia kół stanowią do dziś bardzo poważny problem w eksploatacji taboru kolejowego, szczególnie w zarządach, które nie partycypują w rozwoju nowych rozwiązań konstrukcyjnych i nowych materiałów wdrażanych do eksploatacji, oraz nie wdrażają nowych technik eksploatacji.

\section{Zakończenie}

Hamulce klockowe i tarczowe w najbliższej przyszłości będą nadal powszechnie stosowanymi rodzajami hamulców, przy czym ich zakres stosowania w zależności od technicznej i ekonomicznej przewagi coraz bardziej będzie się rozdzielał.

Dla pojazdów bez napędu i z niewielkimi wymaganiami co do mocy hamowania (do około $450 \mathrm{~kW}$ na zestaw kołowy), hamulec klockowy jest konstrukcyjnie najprostszym i zasadnym rozwiązaniem, szczególnie dla wagonów towarowych. Rozwój wstawek kompozytowych o niskim współczynniku tarcia, podobnym do wstawek $\mathrm{z}$ żeliwa szarego zapewni zmniejszenie hałasu $\mathrm{w}$ wagonach towarowych $\mathrm{i}$ innych pojazdach o prędkości maksymalnej (do 120 $\mathrm{km} / \mathrm{h}$ ) poprzez prostą wymianę wstawek bez dużych nakładów.

Dla dużych mocy hamowania (do $800 \mathrm{~kW}$ na zestaw kołowy) - i w przyszłości być może również dla jeszcze większych - stosowane będą hamulce tarczowe, gdyż tylko one są w stanie skutecznie i w dłuższym czasie (eksploatacji) zagwarantować odprowadzenie ciepła bez niedopuszczalnych (niebezpiecznych) naprężeń $\mathrm{w}$ kołach (szczególnie przy powierzchni tocznej). W pojazdach trakcyjnych na większe prędkości $(120 \div 200 \mathrm{~km} / \mathrm{h})$, które wyposażone są dodatkowo w hamulce dynamiczne dużej mocy uwzględniane obliczeniowo w ogólnej skuteczności hamowania pojazdu (co jest dzisiaj przypadkiem powszechnym), otwartym jest pytanie czy hamulcem bezpieczeństwa powinien być hamulec tarczowy na kołach lub na osiach (lub wałach), czy jednak hamulec klockowy ze względu na swoją prostotę i niskie koszty eksploatacji. $\mathrm{Z}$ tego powodu, że hamulce pneumatyczne nie muszą być często używane w tego typu pojazdach, należałoby zalecać stosowanie hamulca klockowego. W takim przypadku musi być jednak zagwarantowane, by po każdym intensywnym hamowaniu (nagłym i zbliżonym do pełnego) z hamulcem klockowym, nastapiło w krótkim czasie po tym zdarzeniu, niezbyt głębokie przetoczenie powierzchni tocznej kół. Określenie tych hamowań przez sterownik mikroprocesorowy pojazdu jest dzisiaj tak samo proste do zrealizowania jak ,inteligentne" sterowanie hamulcem dynamicznym $\mathrm{z}$ niewielkim uzupełnieniem go przez hamulec klockowy, spełniający rolę ,hamulca czyszczącego", działającego w celu kondycjonowania powierzchni tocznej kół, by utrzymać wysoki współczynnik przyczepności koło-szyna, zapewniający dużą siłę pociągową pojazdu. Wydaje się więc, że hamulec klockowy ze wstawkami żeliwnymi lub kompozytowymi będzie jeszcze długo stosowany w pojazdach szynowych o parametrach mieszczących się $\mathrm{w}$ granicach stosowalności tego hamulca.

\section{Literatura}

[1] Ausschuss CTR Technik und Forschung. Unterausschuss $5 T$ „Bremswesen“. UIC - Frage 5T53:Lärmreduzierung - Einbau von Verbundstoffsohlen in Güterwagen. Teil 2. Bremsbetrieb, Überwachung und Instandhaltung. 29.05.2001

[2] Kazarinov V.M., Inoziemcev V.G., Jasiencev V.F.: Teoreticzeskije osnowy projektirowania $i$ ekspluatacji avtotarmozov. Izdatielstwo „, Transport” 1968

[3] Otto A.W.: Stand der entwicklung von Bremswerkstoffen für Schienenfahrzeuge. ZEV+DET Glas. Ann. 119 (1995) nr 11/12/05

[4] Saumweber E.: Leistungsgrenzen Kombinierter Bremssysteme. ZEV-Glas. Ann. Nr 7/8, 1974

[5] Potenziale und Grenzen der Klotzbremse im ergleich zur Scheibenbremse. ZEV+DET Glas. Ann. 126 (2002) 6/7, str. 290-300.

[6] Zander,C.: Klotzbremsen mit Sintermetallbelägen - Betriebserfahrungen mit Hochleistungslokomotiven. ZEV+DET Glas. Ann. 125 (2001) 4, str. 157-165. 